\title{
Differentiation of Serviceberry Habitats in the Wasatch Mountains of Utah
}

\author{
STEVEN YAKE AND JACK D. BROTHERSON
}

\section{Abstract}

Utah serviceberry (Amelanchier utahensis Koehne) and its habitats were studied in the Wasatch Mountains of central Utah. Twenty-five populations were selected and sampled for various biotic and abiotic environmental variables. Regression, correlation, cluster, and discriminant analyses were used to analyze the data. Sites of northern exposure exhibited a more luxuriant vegetation than southern exposures. Although all the study sites contained Utah serviceberry as a dominant or subdominant plant, they can be classified into three major habitat types according to associated dominants and/or geographical location. These groups are serviceberry-dominated foothill knolls; oak-serviceberrydominated northern exposures; and serviceberry-dominated southerly exposures.

Analyses demonstrated overlap between the major selected habitat types. The most distinct habitat was the foothill knolls; the least distinct was the southern exposed serviceberry habitat. The serviceberry habitat on southerly exposures is environmentally intermediate between the foothill knolls and higher elevation northern exposed sites on which serviceberry shares dominance with oak. Discriminant analysis indicated that $\mathrm{pH}$, slope, sand, soluble salts, and clay were the environmental factors most important in distinguishing between the major habitat types.

Species of the serviceberry genus (Amelanchier) are widespread in North America. Some species are highly prized ornamentals (Theiss 1961), while others are widely recognized for their forage value (Richens 1967; Martinka 1968; Plummer 1969; Stevens 1970). Most of the past work on serviceberry in the West has been done with Saskatoon serviceberry $(A$. alnifolia Nutt.). However, Utah serviceberry (A. utahensis Koehne) is also recognized as an important browse species Plummer 1969) and is found growing throughout much of the western United States (Fig. 1).

In the past, there has been some confusion concerning the characteristics of various Amelanchier species. Cruise (1964) indicated that hybrids occur freely in the genus and that specific limits have been difficult to determine. Historically, Utah serviceberry has been considered a variety or subspecies of Saskatoon serviceberry (Jones 1946), the two being separated by the pubescent mature leaves of Utah serviceberry (Jones 1946; Harrington 1954). However, some populations of what otherwise appears to be Utah serviceberry have glabrous leaves in Arizona and Nevada (Jones 1946). The two taxa appear to prefer different habitats, with Utah serviceberry reported as preferring dryer sites than Saskatoon serviceberry (Plummer 1969). Recent taxonomic treatments (Hitchcock and Cronquist 1973; Welsh and Moore 1973) consider Utah serviceberry to be a valid species.

The authors are graduate student and associate professor. Department of Botany and Range Science. Brigham Young University. Provo. Utah 84602

lianuicript received August 7. 1979.

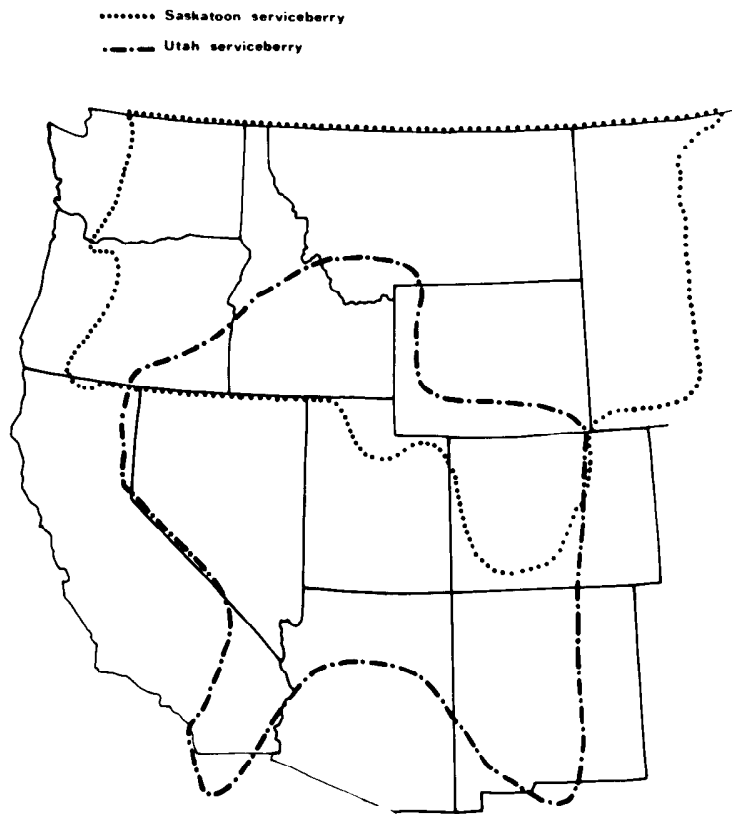

Fig. 1. Map of the distribution in the western United States of Utah and Saskatoon serviceberry.

Utah serviceberry is common in several of the life zones of the Wasatch Mountains. It occurs in conifer stands, in mixed mountain brush stands, and in mixtures with Utah juniper and big sagebrush (Anderson 1974; Christensen 1964; Plummer 1969).

Little work has been reported on habitat relations and composition of plant communities that support Utah serviceberry as a dominant or subdominant species. The purpose of this study was to document the habitat relationships and community composition of Utah serviceberry to provide useful information to land managers.

\section{Study Area}

Populations of Utah serviceberry were studied in the summer of 1975 in the Diamond Fork and Sheep Creek drainages of the Wasatch Mountains in Central Utah (Fig. 2). The study area supports oak (Quercus gambelii) and other mountain brush species intermingled in a complex pattern. This vegetatve mosaic forms a discontinuous transition zone between aspen and coniferous forests above and grassland and/or sagebrush covered foothills below. Annual precipitation in the study area averages about $50 \mathrm{~cm}$ (Bailey 1977). Elevation ranges from 2,050 to $2,225 \mathrm{~m}$. The areas have served as a summer range since the late 1800 's for sheep and cattle and locally as valuable winter range for mule deer. In places, overgrazing by domestic livestock is apparent, but in general the ranges are in good condition, as can be seen from the relative importance of major plant species (Table 1). 


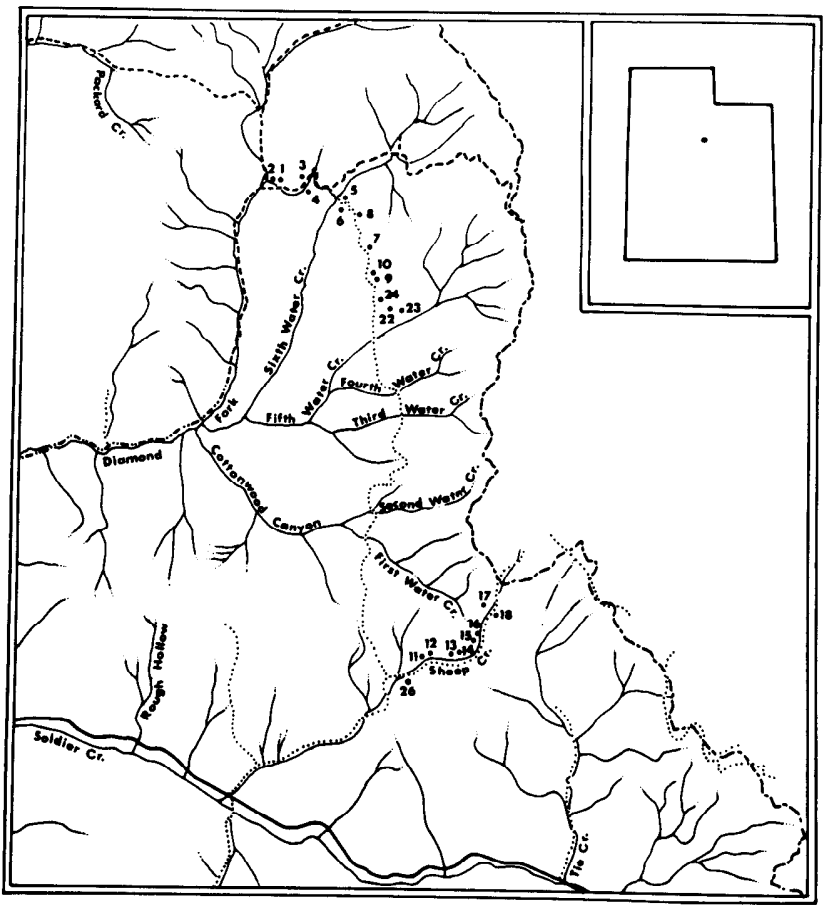

Fig. 2. Map of the study area showing study site locations.

\section{Methods}

Twenty-five populations of Utah serviceberry were selected in three habitat types. The first type is typified by an oak canopy overstory with an understory in which Utah serviceberry is prominent. Ten oakserviceberry stands were selected for study and adjacent to them ten serviceberry dominated stands were chosen. The serviceberry stands were similar to the oak-serviceberry stands except that they lacked an oak overstory and occurred on more southerly exposures. The third group of stands (five in number) were also dominated by Utah service-berry but were situated on dry, foothill knolls. At each site a 20 $\times 20 \mathrm{~m}$ study plot (.04 ha) was delineated. Each plot was subsampled with twenty-five quadrats $\left(0.25 \mathrm{~m}^{2}\right)$ distributed uniformly across the surface of the plot in five rows of five quadrats each. An estimate of commonness of understory species were arrived at by dividing each quadrat into four subunits of equal size and noting the occurrence of the species in both quadrats and quadrat subunits. Living plant cover, litter, rock, and bare soil were estimated using the cover class categories $(1=0-5 \%, 2=5-25 \% ; 3=25-50 \% ; 4=50-75 \% ; 5$ $=75-95 \% ; 6=95-100 \%$ ) suggested by Daubenmire (1959). Plant cover was subdivided into shrubs, perennial forbs, perennial grasses, and annuals for estimating purposes. In addition, species appearing in the .04-ha study plot but not in the $0.25 \mathrm{~m}^{2}$ quadrats were also recorded.

Soil samples using a tube sampler soil probe were taken from the top $15 \mathrm{~cm}$ of the soil profile in five of the $0.25-\mathrm{m}^{2}$ quadrats. Samples were taken in quadrats at the corners and the center of each $20 \times 20 \mathrm{~m}$ study plot and were pooled for analysis. Soil texture was determined by procedures outlined by Bouyoucos (1936, 1951). The hydrogen ion concentration $(\mathrm{pH})$ and total soluble salts were determined on a 1:1 water to soil paste (Russell 1948). Soil depth was estimated from 1-m penetrometer probes (Greenwood and Brotherson 1978).

Aspect was determined for each site and transformed for analysis using the equation $A^{\prime} \cos (A \max -A)+1$ (Beer et al. 1966). In this equation $A^{\prime}$ is the transformed aspect code, $A$ max is the aspect which has the greatest growth potential (in this case $45^{\circ}$ ), and $A$ equals the heading in azimuth degrees. Under this system a northeast aspect would receive a designation of 2.0 while a southwest aspect would be designated with a 0.0 . Intermediate aspect would then vary from 2 to 0 in both directions. Elevation for each site was estimated to 7.5 minute quadrangle topographic maps.
Table 1. Prominent species in the three habitat types along with their listed importance values. Figures represent constancy times average percent cover.

Oak-

Foothill-

serviceberry Serviceberry serviceberry

\begin{tabular}{|c|c|c|c|}
\hline Poapratensis & 14 & - & - \\
\hline Lathyrus pauciflorus & 11 & - & - \\
\hline Stipa columbiana & 34 & 5 & - \\
\hline Physaria newberryi & 28 & 6 & - \\
\hline Penstemon leonardii & 21 & 19 & - \\
\hline Astragalus convallarius & 20 & 17 & - \\
\hline Taraxacum officinale & 19 & 24 & - \\
\hline Bromus ciliatus & 15 & 4 & - \\
\hline Rosa woodsii & 14 & 12 & - \\
\hline Melica bulbosa & 10 & 4 & - \\
\hline Oryzopsis hymenoides & 3 & 5 & - \\
\hline Comandra pallida & 102 & 17 & 2 \\
\hline Symphoricarpus oreophilus & 91 & 66 & 22 \\
\hline Aster adscendens & 53 & 15 & 1 \\
\hline Agropyron cristatum & 44 & 50 & 21 \\
\hline Allium acuminatum & 34 & 18 & 2 \\
\hline Machaeranthera canescens & 32 & 29 & 10 \\
\hline Amelanchier utahensis & 31 & 27 & 11 \\
\hline Chrysothamnus viscidiflorus & 28 & 15 & 6 \\
\hline Artemisia tridentata & 16 & 13 & 9 \\
\hline Purshia tridentata & 16 & 16 & 5 \\
\hline Balsamorhiza sagittata & 12 & 14 & 2 \\
\hline Quercus gambellii & 10 & 2 & 1 \\
\hline Tragopogon dubius & 9 & 2 & 1 \\
\hline Prunus virginiana & 6 & 3 & 7 \\
\hline Viola adunca & 4 & 4 & 5 \\
\hline Bromus carinatus & 2 & 31 & 13 \\
\hline Chaenactis douglasii & 5 & 7 & 3 \\
\hline Symphoricarpus tetonsis & - & 10 & - \\
\hline Elymus glaucus & - & 7 & - \\
\hline Chenopodium fremontii & 12 & 32 & 79 \\
\hline Mahonia repens & 17 & 47 & 55 \\
\hline Koeleria cristata & 5 & 20 & 53 \\
\hline Eriogonum brevicaule & 1 & 4 & 44 \\
\hline Eriogonum heracleoides & 9 & 14 & 30 \\
\hline Cynoglossum officinale & 5 & 4 & 11 \\
\hline Gilia aggregata & 1 & 2 & 8 \\
\hline Oenothera caespitosa & 1 & 2 & 6 \\
\hline Gayophytum ramosissimum & - & 3 & 9 \\
\hline Poanavadensis & - & 2 & 4 \\
\hline Viguiera multiflora & - & - & 34 \\
\hline Crepis acuminata & 4 & - & 18 \\
\hline Agropyron trachycaulum & 1 & - & 14 \\
\hline Mentzelia albicaulis & - & - & 6 \\
\hline Chrysothamnus nauseosus & - & - & 5 \\
\hline Lithospermum ruderale & - & - & 3 \\
\hline
\end{tabular}

Within each plot seedlings and mature plants of serviceberry were counted. Seven mature individuals were measured for the following: stems per clump, height of clump, game use, age class, and incidence of cedar-apple rust (Gymnosporangium inconspicuum Keron). Game use was estimated on a scale of 1 (seedings) through 4 (decadent plants). In addition, the three largest individuals were aged from a stem section taken from the largest stem of the clump. Statistical analyses used were regression, correlation, analysis of variance, Newman-Keuls multiple range test (Cochran and Snedecor 1976), cluster (Sneath and Sokel 1973), and discriminant (Klecka 1975). Diversity values were computed using the equation $B=1 / \sum p i^{2}$ where $B$ is the diversity index and $p i$ is a measure of the relative abundance of a species in a given plot (MacArthur 1972).

\section{Results and Discussion}

Prominent species in the three habitat types along with their importance values are listed in Table 1 . As shown, serviceberry becomes increasingly important as one moves from the moist northern exposed oak-serviceberry sites to the dry foothill knolls. Diversity figures (Table 2) indicate the oak-serviceberry 
Table 2. Vegetational parameter relationship existent between the three habitat types of Utah serviceberry. Figures represent means. Significance levels based on analysis of variance statistics.

\begin{tabular}{|c|c|c|c|}
\hline & $\begin{array}{l}\text { Oak- } \\
\text { serviceberry }\end{array}$ & Serviceberry & $\begin{array}{l}\text { Foothill- } \\
\text { serviceberry }\end{array}$ \\
\hline Total living cover & 36.84 & 30.92 & $24.08 *$ \\
\hline Percent shrub cover & 58.51 & 57.91 & $34.54 * *$ \\
\hline Percent forb cover & 35.59 & 25.57 & 24.84 \\
\hline Percent grass cover & 14.40 & 11.73 & $28.30^{*}$ \\
\hline Percent annual cover & 0.80 & 4.58 & 10.76 \\
\hline Mean clump age/stand & 28.90 & 24.53 & $16.54 * *$ \\
\hline Mean clump height/stand $(\mathrm{cm})$ & 121.50 & 127.90 & $78.60 * *$ \\
\hline Mean stems/clump & 21.09 & 16.86 & 28.20 \\
\hline Mean density/stand & 32.20 & 27.90 & 32.00 \\
\hline $\begin{array}{l}\text { Reproduction (mean no. of } \\
\text { individuals/plot) }\end{array}$ & 2.68 & 2.88 & 2.79 \\
\hline Game use & 2.10 & 2.12 & 2.29 \\
\hline Incidence of cedar apple rust & 1.54 & 1.50 & 1.40 \\
\hline Percent litter cover & 23.00 & 9.30 & 18.00 \\
\hline Diversity & 10.27 & 9.35 & 9.23 \\
\hline
\end{tabular}

sites showed higher mean diversities even though the differences were not statistically significant. Total living plant cover increased from the foothill-serviceberry sites to the northern exposed oak-serviceberry sites. The oak-serviceberry sites also had a higher percentage of shrubs and forbs, more litter, older serviceberry plants, and slightly greater game use (Table 2).

Serviceberry dominated habitats on south slopes had more annuals and fewer forbs in their vegetation than the oak-serviceberry sites but both showed similar shrub cover (Table 2). Serviceberry plants were on the average younger and taller on these southern exposed sites.

The vegetation of the foothill-serviceberry sites was low in shrub cover, high in grasses and annuals, and showed limited game use. The serviceberry individuals on these sites were younger, smaller, and more shrubby than on the other habitats.

In order to clearly define environmental similarities and differences between the three habitat types discriminant analysis (Klecka 1975) was used. The abiotic parameters used in this analysis were soil texture, soil $\mathrm{pH}$, soil soluble saltes, elevation, aspect, and slope. The discriminant analysis correctly classified on the basis of these six parameters $70 \%$ of the oak-serviceberry sites, $80 \%$ of the foothill-serviceberry sites, and only $40 \%$ of the serviceberry sites (Table 3). Those oak-serviceberry and foothill-serviceberry sites not classified correctly were placed with the serviceberry habitat. This suggests that the habitat of serviceberry sites is intermediate between that of oak-serviceberry and the foothill-serviceberry. Comparisons based on abiotic factors were made among the three groups (Table 4).

Table 3. Percent of stands classified correctly into three habitat types of Utah serviceberry by discriminant analysis utilizing environmental data.

\begin{tabular}{lcccc}
\hline \hline & \multicolumn{3}{c}{ Percent classified in each group } \\
\cline { 3 - 5 } Vegetation & No. of stands & $\begin{array}{c}\text { Oak- } \\
\text { serviceberry }\end{array}$ & Serviceberry & $\begin{array}{c}\text { Foothill- } \\
\text { serviceberry }\end{array}$ \\
\hline Foothill- & 5 & & 20 & 80 \\
serviceberry & 10 & 30 & 40 & 30 \\
Serviceberry & 10 & 70 & 30 & \\
Oak- & & & & \\
serviceberry & & & & \\
\hline
\end{tabular}

Table 4. Environmental parameter relationships existent between the three habitat types of Utah serviceberry. Figures represent means. Significance levels hased on analysis of variance statistics.

\begin{tabular}{lccc}
\hline Site-parameter & Oak-serviceberry & Serviceberry & $\begin{array}{c}\text { Foothill- } \\
\text { serviceberry }\end{array}$ \\
\hline $\mathrm{pH}$ & 7.40 & 7.64 & $7.9^{*}$ \\
Slope $(\%)$ & 13.60 & 15.2 & 19.0 \\
Sand $(\%)$ & 39.46 & 44.84 & $64.24^{*}$ \\
Silt $(\%)$ & 22.24 & 21.0 & 10.80 \\
Clay $(\%)$ & 38.40 & 34.26 & $24.96^{*}$ \\
Salt $(\mathrm{ppm})$ & 377.70 & 335.6 & 393.60 \\
Aspect & .79 & .75 & .66 \\
Elevation $(\mathrm{m})$ & 2163.00 & 2174.00 & 2131.00 \\
Soil depth $(\mathrm{dm})$ & 1.90 & 1.33 & 1.48 \\
Exposed rock $(\%)$ & 10.68 & 15.56 & 7.28 \\
Bare soil $(\%)$ & 21.8 & 25.94 & $39.92^{* *}$ \\
\hline
\end{tabular}

Significance level $=0.05$

Significance level $=0.01$

The figures represent means and define the observed environmental similarities and/or differences found among the three habitats. The serviceberry-dominated sites represent a somewhat intermediate habitat between the other two. This is, perhaps, best evidenced by $\mathrm{pH}$ (Table 4), which gradually increases from oak-serviceberry to foothill-serviceberry and was the variable selected via discriminant analysis as the best discriminator between the three habitats.

The textural classes, sand, silt, and clay along with $\mathrm{pH}$ and percent bare soil were the variables found to be significantly different among the three habitats according to analysis of variance (Table 4 ). When the significant relationships were examined (Table 5) all the significant pairs (Newman-Keuls multiple range test) occurred between the foothill-serviceberry and oak-serviceberry habitats while no significant differences existed between the foothill-serviceberry and serviceberry habitats or between the serviceberry and oak-serviceberry habitats. These relationships also indicate that the serviceberry habitat is not significantly different from either the foothillserviceberry or the oak-serviceberry habitats but is transitional or intermediate between them.

Table 5. Results of analysis of variance on environmental variables found to be significantly different between three habitat types of Utah serviceberry.

\begin{tabular}{clc}
\hline Parameter & \multicolumn{1}{c}{ Habitat types } & Significance \\
pH & Foothill-serviceberry, Oak-serviceberry & .05 \\
Clay & Foothill-serviceberry, Oak-serviceberry & .05 \\
Silt & Foothill-serviceberry, Oak-serviceberry & .01 \\
Sand & Foothill-serviceberry, Oak-serviceberry & .05 \\
Bare & & \\
soil & Foothill-serviceberry, Oak-serviceberry & .01 \\
\hline
\end{tabular}

As a part of the discriminant analysis, functions are derived which compute an artificial index for classifying the sites. Three functions were derived from our analysis and their coefficient values are shown in Table 6.

The coefficients correspond to the values of the discriminating variables given in the input data and are used to compute a discriminant score. The discriminant score is computed by multiplying the discriminating variables by their corresponding coefficients. By summing these and adding the constant, it is possible to compute ordination values. The coefficients are derived in a way which produces the discriminant scores in standard form. This means that over all cases in the analysis, a 


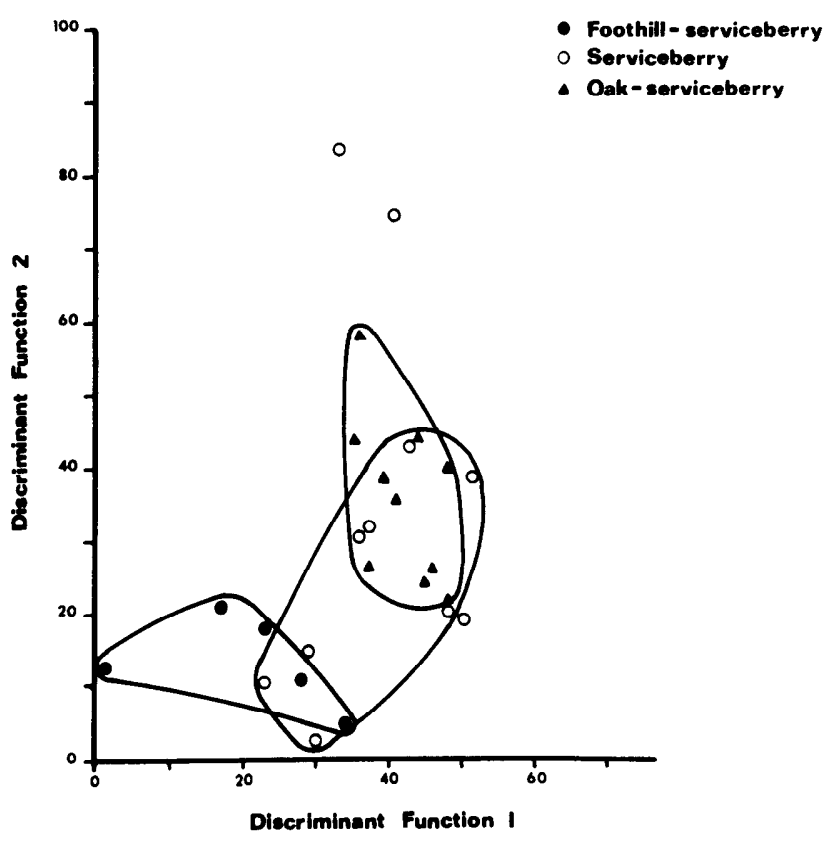

Fig. 3. Two dimensional scheme of the interrelationships of the 25 stands of Utah serviceberry as depicted by discriminant analysis.

single function score will have a mean of zero and a standard deviation of one. Therefore, any score for a single case represents the number of standard deviations that case is away from the mean of all cases on a discriminant function. Each case will have a score on each function.

By utilizing functions 1 and 2 (Table 6) to compute the ordination values the sites were plotted in two dimensional space (Figure 3 ). It can been seen from this figure that the sites of the serviceberry habitat exhibit a much larger spread than those of the other groups. The lines around each group are only approximate and were placed there in an effort to delineate the probable boundaries of each group. As shown, $80 \%$ of the serviceberry sites fall in a pattern placing the group somewhat intermediate between the oak-serviceberry and foothill-serviceberry habitats.

\section{Table 6. Discriminant functions generated in discriminant analysis of environmental data related to the three habitat types of Utah Service- berry.}

\begin{tabular}{llrr}
\hline $\begin{array}{l}\text { Discriminating- } \\
\text { variables }\end{array}$ & \multicolumn{3}{c}{ Discriminant Function Coefficients } \\
& Function $1^{*}$ & \multicolumn{1}{c}{ Function 2 } & Function 3 \\
\hline Salt & -0.00156 & -0.00021 & 0.00146 \\
pH & -0.2773 & 0.21515 & -0.21880 \\
Sand & -0.01896 & -0.01000 & 0.00502 \\
Silt & -0.03514 & 0.00164 & 0.00166 \\
Slope & 0.00486 & -0.01878 & -0.00950 \\
Constant & 4.15249 & -0.83330 & 1.01480 \\
\hline
\end{tabular}

By multiplying the discriminating variables by their respective coefficient. summing llk'se and adding the constant, it is possible to compute ordination values.

To define the relationships between environmental factors and biological parameters stepwise regression analyses were run. The analyses were grouped into two general categories (Table 7): those dealing with charactristics of community vegetation and those dealing with charactristics of Utah serviceberry. The community characteristics examined were total living plant cover, and percent cover of shrubs, forbs, grasses and annuals in the vegetation. The serviceberry
Table 7. Relationships between dependent and independent variables along with equations generated in stepwise regression analysis.

\begin{tabular}{llll}
\hline \hline Equation & Sig. & $R^{2}$ & $r$ \\
\hline 1. Living cover $=-.27 X_{2}-5.4 X_{3}+.24 X_{4}+6.34 X_{5}+53.2$ & .001 & .85 & .92 \\
2. \% shrubs $=7.93 X_{1}+.34 X_{4}+12.36 X_{6}+2.7$ & .05 & .32 & .57 \\
3. \% forbs $=7.4 X_{1}+.54 X_{7}+.48 X_{2}+.42 X_{9}-7.9$ & .05 & .41 & .64 \\
$4 . \%$ grass $=.12 X_{13}-.36 X_{2}-.41 X_{12}-.01 X_{15}+41.8$ & .001 & .61 & .78 \\
$5 . \%$ annuals $=2.91 X_{1}-.42 X_{16}+19.8$ & .05 & .26 & .51 \\
6. Age $=.14 X_{12}-.33$ & .001 & .55 & .74 \\
7. Density $=4.78 X_{1}+11.22 X_{17} .05 X_{8}+29.4$ & .01 & .43 & .65 \\
8. Serviceberry height $=30.04 X_{6}-2.03 X_{1}+107.5$ & .001 & .51 & .71 \\
9. Game use $=29 X_{5} X_{1}-.001 X_{17}+.004 X_{14}+3.6$ & .01 & .52 & .72 \\
10. Disease $=.009 X_{4}-.18 X_{1}-.01 X_{9}{ }^{\pi+03} X_{18}+.002 X_{17}-2.7$ & .001 & .71 & .84 \\
11. Reproduction $=-.16 X_{1}-.007 X_{19}-.009 X_{10}-.40 X_{6}+4.2$ & .05 & .36 & .60
\end{tabular}

$X_{1}=$ aspect: $X_{0}=\%$ rock cover; $X_{3}=\mathrm{pH} ; X_{4}=$ fines; $X_{5}=$ soil depth: $X_{6}=$ game use; $X_{7}=$ litter: $X_{\mathrm{s}}=$ soluble salts; $X_{4}=$ clay; $X_{10}=$ clumps/stand (density); $X_{11}^{6}=$ bare soil: $X_{10}^{7}=$ \% shrub: $X_{13}=$ sand; $X_{14}=$ height: $X_{15}=$ resistance; $X_{115}=$ living cover: $X_{17}=$ elevation: $X_{10}=$ slope: $X_{13}=\%$ grass.

characteristics studied were age, density, height, reproduction, game use, and incidence of disease.

Total living plant cover correlated with soil depth, $\mathrm{pH}$, percent fines, and percent rock cover (equation 1, Table 7). As soil depth increased, plant cover also increased. This would indicate more fertile growing conditions with respect to plant cover and/or better soil building processes and watershed protection due to increased canopy coverage. Hydrogen ion concentration $(\mathrm{pH})$ would also be influenced by cover, becoming lower with increased litter and litter decomposition, a result of greater cover.

With respect to the general ecology of growth form types in the vegetation (equations 2-5, Table 7) the data indicate that shrub cover is highest on sites with fine soils, a somewhat northerly aspect, and elevated game use. Forb cover follows similar patterns with the added parameters of high clay content in the soil and increased amounts of litter correlating and suggesting more moist and fertile conditions on these sites. Grass cover on a site shows different trends correlating with percent sand and low soluble salts in the soil, exposed rock, and low shrub cover in the vegetation. The grasses, then, do better on dryer and less fertile sites as the high sand and low soluble salt values indicate. Annual cover was negatively associated with total living cover and aspect indicating their restriction to the poorer, dryer areas of southern exposure where there are more open areas (Table 4) and competition is less severe. This would parallel data published by Crowther and Harper (1965) wherein they also found the annual habit most important on dry inhospitable sites.

The characteristics of serviceberry examined in correlation analysis (equations 6-11, Table 7) indicate that the older, taller, more dense stands were those of higher elevation, moist northern slopes with deeper, more fertile soils. Bare soil was least in these areas. On these northern exposed sites the snow would stay longer making them more moist and thus more conducive for healthy growth and longer life of the serviceberry plants.

A factor correlating with serviceberry height was game use. The positive association is due to the fact that the less use there was the higher our recorded use value. This would indicate that the plants get taller when used less as forage.

The incidence of the disease, cedar apple rust, on Utah serviceberry was highest at the lower elevations, on the more northerly exposures and steeper slopes. The disease also hit hardest those plants growing on low salt and fine textured soils. 
Reproduction in Utah serviceberry correlated to four independent variables, all of which were negatively associated. The most important variable was game use. With increased game use, Utah serviceberry seedlings due to their small size and succulence would be more likely to be used by the foragers. This would mean less chance of encountering seedlings on the site itself. The other variables-aspect, density of serviceberry shrubs, and percent grass in the flora-are all associated in such a way as to place the sites with greatest reproduction on the more moist northern exposures with high densities of Utah serviceberry. A high percentage of grass cover on the habitat may make it difficult for seedlings to become established due to competition or grass may indicate a xeric habitat of southern exposure.

Game use correlated with four factors. These include: aspect, soil depth, height of serviceberry plants, and elevation. Except for height of serviceberry plants, these factors apparently act on game use indirectly through their effect on the shrub. For example it is difficult to conceive of aspect directly affecting the browsing habits of the herbivore. However, the more moist, northerly exposure should produce more palatable forage and thus more animal use. The more severely browsed specimens were found predominately on the northern exposures, at higher elevtions in the oak-serviceberry habitat. This was apparent for sites less than 100 yards apart.

Game use of Utah serviceberry was also highest where shrubs and torbs predominate. As mule deer are known to feed heavily on forbs during the summer season (Kufeld ct al. 1973) the higher percentage of forbs on sites where the shrubs show greater game use may indicate preferential habitat for foraging and thus heavier game use of these sites should not be considered accidental.

In general, several basic trends can be observed. The shrubs and forbs are positively associated with the finer soils and tend to occur together. Both shrubs and living cover are negatively correlated with grasses and annuals which prefer the sandy, coarser soils. Living cover is also positively associated with percent fines in the soil and with sites of greater soil depth. Other factors also influenced by or correlated to living cover include aspect and acidity. The acidity of the soil increases as the living cover increases. Aspect also influences percent forbs in the vegetation and the number of stems per serviceberry clump. This would indicate that the wetter northern exposures support a more lush vegetation.

Utah serviceberry as a species occupies a rather wide range of habitat types. It does in our arca, however, appear to do best on moist northern exposures at higher elevation with deep, finely textured soils which exhibit low $\mathrm{pH}$ and soluble salts. On such sites the serviceberry shrubs show greater incidence of game use and disease. This relationship is most interesting and might best be explained due to the increased vigor and greater succulence of the individual plant on such an area. It would appear likely that the succulent plant would also be more easily parasitized than those plants occupying sites of more stressed habitats, the succulent plants should also be more preferable as forage.

\section{Literature Cited}

Anderson, D.L. 1974. Ecological aspects of Cerocarpus montanus Raf. communities in Central Utah. Unpublished master's thesis. Dept. of Botany and Range Science. Brigham Young University, Provo, Utah. 84 p.

Bailey, R.G. 1977. Ecoregion descriptions - to accompany the map of Ecoregions of the United States. Preliminary repor-Forest Service, U.S. Department of Agriculture in cooperation with the U.S. Fish and Wildlife Service, Ogden, Utah.

Beers, T.W., P.E. Dress, and L.C. Wensel. 1966. Aspect transformation in site productivity research. J. of For. 64:691-2.

Bouyoucos, G.J. 1936. Directions for making mechanical analysis of soils by the hydrometer method. Soil Sci. 42:225-230.

Bouyoucos, G.J. 1951. A recalibration of the hydrometer method for making mechanical analysis of soils. Agron. J. 43:434-438.

Christensen, E.M. 1964. Succession in a mountain brush community in Central Utah. Proc. Utah Acad. of Sci. Arts and Letters. 41 (1):10-13

Cochran, W.G., and G.W. Snedecor. 1976. Statistical Methods. Iowa State University Press. Ames, Iowa. 593 p.

Crowther, E.G., and K.T. Harper. 1965. Vegetational and edaphic characteristics associated with Aspen "strips" in Big Cottonwood canyon. Proc. Utah Acad Sci., Arts and Letters 42:222-230.

Cruise, J.E. 1964. Studies of natural hybrids in Amelanchier. Canadian J. Bot. 42:651-664.

Daubenmire R. 1959. A canopy-coverage method of vegetational analysis. Northwest Sci. 33:43-66.

Greenwood, L.R., and J.D. Brotherson. 1978. Ecological relationships between pinyon-juniper and true mountain mahogany stands in the Uintah Basin, Utah. J. of Range Manage. 31:164-167.

Harrington, H.D. 1954. Manual of the Plants of Colorado. Swallow Press Inc. Chicago. $666 \mathrm{p}$.

Hitchcock, C.L., and A. Cronquist. 1973. Flora of the Pacific Northwest. University of Washington Press, Seattle. $730 \mathrm{p}$.

Jones, G.N. 1946. American Species of Amelanchier. The University of Illinois Press. Urbana. III. $126 \mathrm{p}$.

Klecka, W.R. 1975. Discriminant analysis, pp 434-467. In: Nie, N.H.H. Hull, J.G. Jenkins. K. Steinbrenner, and D.H. Bent (ed.). Statistical Package for the Social Sciences 2nd ed. McGraw-Hill Book Co. New York 1975. 675 p.

Kufeld, R.C., O.C. Wallmo, and D. Feddema. 1973. Foods of the Rocky Mountain mule deer U.S. Forest Service Research Paper RM-111. 31 p.

MacArthur, R.H. 1972. Geographical ecology: patterns in the distribution of species. Harper and Row, New York. 251 p.

Martinka, C.J. 1968. Habitat relationships of white-tailed and mule deer in Northern Montana. J. Wildl. Manage. 32(3):558-565.

Plummer, A.P. 1969. Restoring big game range in Utah. Pub. No. 683. Utah Division of Fish and Game. 183 p.

Kichens, V.T. 1967. Characteristics of mule deer herd and their range in Northeastern Utah. J. Wildl. Manage. 31:651-666.

Russell, D.A. 1948. A Laboratory Manual for Soil Fertility. Students 2nd ed. Dubuque lowa, Wm. Brown Co. $56 \mathrm{p}$

Sneath, P.H.A., and R.R. Sokal. 1973. Numerical Taxonomy-the Principles and Practice of Numerical Classification. W.H. Freeman and Company. San Francisco, California. 573 p.

Stevens, D.R. 1970. Winter ecology of moose in the Gallatin Mountains. Montana. J. Wild. Manage. 34:37-46.

Theiss, L.E. 1961. Small garden? Plant a serviceberry. Organic Gard. and F 8:37-9 Oct.

Welsh, S.L., and G. Moore. 1973. Utah Plants, Third ed. Brigham Young U. Press. Provo, Utah. 474 p 